\title{
PEMANFAATAN SISTEM MONITORING KEGIATAN TRI DHARMA PT OLEH LEMBAGA PENJAMINAN MUTU INTERNAL UNIVERSITAS VICTORY SORONG
}

\author{
Frits Gerit John Rupilele* \\ Fakultas Ilmu Komputer Universitas Victory Sorong \\ fritsrupilele@gmail.com
}

\begin{abstract}
ABSTRAK
Implementasi sistem penjaminan mutu internal (SPMI) pada perguruan tinggi (PT) merupakan siklus SPMI yang meliputi penetapan standar Dikti, pelaksanaan standar, evaluasi pelaksanaan standar, pengendalian pelaksanaan standar, dan peningkatan standar Dikti. Kendalakendala implementasi SPMI seperti yang terjadi pada Lembaga Penjaminan Mutu Internal (LPMI) Universitas Victory Sorong (UNVIC) adalah kesulitan dalam melakukan monitoring dan evaluasi karena menggunakan sistem manual sehingga sulit dalam melakukan pengumpulan data, perekapan dan pembuatan laporan hasil kegiatan yang membutuhkan waktu yang cukup lama untuk mendapatkan hasilnya. Pemanfaatan sistem informasi menjadi solusi yang mendukung semua kegiatan penjaminan mutu termasuk monitoring dan evaluasi terhadap pelaksanaan standar mutu. Implementasi sistem ini membutuhkan kegiatan berupa workshop pemanfaatan sistem terhadap pengguna sistem antara lain mahasiswa, dosen, dan pimpinan PT dimana pelaksanaan kegiatan ini memastikan semua pengguna sistem mengetahui peran, fungsi dan prosedur sistem dalam melaksanakan kegiatan Tri Dharma PT. Sistem ini akan menghasilkan output berupa laporan data kegiatan Tri Dharma pada semua program studi di UNVIC Sorong yang meliputi kegiatan pembelajaran di kelas, penelitian dan kegiatan pengabdian kepada masyarakat yang secara langsung dapat dilihat dan dimonitoring oleh pimpinan PT.
\end{abstract}

Kata kunci: Sistem Monitoring, Tri Dharma PT, Penjaminan Mutu Internal.

\begin{abstract}
The implementation of the internal quality assurance system (SPMI) in higher education (PT) is a cycle of SPMI which includes the establishment of Higher Education standards, implementing standards, evaluating the implementation of standards, controlling the implementation of standards, and improving Dikti standards. Constraints to implementing SPMI as happened at the Victory Sorong University Quality Assurance Agency (LPMI) are difficulties in monitoring and evaluating because they use manual systems making it difficult to collect data, recapitulate and produce reports on activities that require time. long enough to get the results. The use of information systems is a solution that supports all quality assurance activities including monitoring and evaluation of the implementation of quality standards. The implementation of this system requires an action in the form of a workshop on system utilization for system users including students, lecturers, and PT leaders where the implementation of this activity ensures all system users know the role, functions and system procedures in carrying out Tri dharma activities of PT. This system will produce output in the form of reports on Tri dharma activity data in all study programs at UNVIC Sorong which includes classroom
\end{abstract}


learning activities, research and community service activities that can be directly seen and monitored by the leadership of $P T$.

Keyword: Monitoring System, Tri Dharma PT, Internal Quality Assurance.

\section{PENDAHULUAN}

Perguruan tinggi (PT) sebagai satuan pendidikan yang menyelenggarakan pendidikan tinggi yang mengemban tugas untuk penyelenggaraan kegiatan Tri dharma PT meliputi Pendidikan dan pembelajaran, penelitian, dan pengabdian kepada masyarakat yang merujuk kepada standar nasional pendidikan tinggi (SN-Dikti) (Rupilele et al., 2018). Kualitas PT menjadi suatu kunci yang sangat penting dalam pengembangan manajemen akademik maupun nonakademik. PT memiliki tugas dan tanggungjawab untuk menghasilkan sumberdaya manusia yang bermutu dan mampu berkompentisi baik pada skala nasional maupun global. Menurut Pasal 51 UU Dikti, Pendidikan Tinggi yang bermutu merupakan Pendidikan tinggi yang menghasilkan lulusan yang mampu secara aktif mengembangkan potensinya dan menghasilkan ilmu pengetahuan dan/atau teknologi yang berguna bagi masyarakat, bangsa, dan negara. Untuk mendapatkan Pendidikan tinggi yang bermutu tersebut, Pemerintah menyelenggarakan Sistem Penjaminan Mutu Pendidikan Tinggi (SPM Dikti). SPM Dikti adalah Kegiatan sistemik untuk meningkatkan mutu Pendidikan tinggi secara berencana dan berkelanjutan. Adapun mutu Pendidikan tinggi adalah tingkat kesesuaian antara penyelenggaraan Pendidikan tinggi dengan Standar Dikti yang terdiri atas SN-Dikti dan Standar Dikti yang ditetapkan oleh setiap PT.

Sistem penjaminan mutu di PT dilakukan secara internal dan eksternal, penjaminan mutu internal dilakukan oleh PT itu sendiri dengan membentuk suatu lembaga/badan/unit yang bertanggung jawab terhadap monitoring dan evaluasi penyelenggaraan pendidikan, penelitian dan pengabdian kepada masyarakat. Sementara itu penjaminan mutu eksternal dilakukan oleh pemerintah melalui Badan Akreditasi Nasional Pendidikan Tinggi (BAN-PT), Lembaga Akreditasi Mandiri (LAM) yang telah diakui oleh pemerintah atau oleh lembaga lembaga lain yang kredibel.

Universitas Victory Sorong (UNVIC Sorong) adalah salah satu PT swasta yang berada di propinsi Papua Barat, yang berdiri pada Tahun 2008 yang memiliki visi "melaksanakan kegiatan transfer ilmu pengetahuan dan teknologi kepada mahasiswa dalam proses pembetukan sumber daya manusia yang berkualitas, berbudi luhur serta bersifat professional 
yang berwawasan global, melakukan pengkajian dan pengembangan IPTEK”. Untuk mewujudkan visi tesebut UNVIC Sorong mempunyai salah satu Lembaga Penjaminan Mutu Internal (LPMI) yang bertugas untuk meningkatkan mutu Pendidikan dengan menjalankan sistem penjaminan mutu internal (SPMI) yang berfungsi merumuskan dan menetapkan standar mutu, melaksanakan standar, mengevaluasi dan mengendalikan serta meningkatkan standar mutu pada PT. Implementasi SPMI pada UNVIC Sorong bertujuan menjamin bahwa setiap kegiatan penyelenggaraan pendidikan tinggi di PT terjamin mutunya, melakukan evaluasi untuk menemukan kekuatan dan kelemahannya sehingga dapat dilakukan perubahan ke arah perbaikan secara berkelanjutan dan hasil pelaksanaan SPMI adalah kesiapan semua unit untuk mengikuti proses akreditasi atau penjaminan mutu eksternal.

Mekanisme implementasi SPMI adalah dengan menjalankan silkus SPMI yang disingkat PPEPP, antara lain Penetapan Standar Dikti, Pelaksanaan Standar Dikti, Evaluasi pelaksanaan Standar Dikti, pengendalian pelaksanaan Standar Dikti, dan Peningkatan Standar Dikti. SPMI UNVIC Sorong telah menjalankan tahapan siklus SPMI sampai pada monitoring dan evaluasi pelaksanaan standar. Kendala-kendala LPMI UNVIC Sorong adalah melakukan monitoring terhadap pelaksanaan kegiatan Tri dharma yang meliputi monitoring proses pembalajaran, penelitian, dan kegiatan pengabdian kepada masyarakat. Salah satu bentuk monitoring proses pembelajaran yang pernah dilaksanakan adalah dengan membagikan jurnal perkuliahan yang berbentuk formulir/dokumen kertas untuk diisi pada setiap kelas untuk semua program studi pada UNVIC Sorong, hal ini menjadi sangat tidak efisien karena LPMI UNVIC kesulitan dalam melakukan pengumpulan data, perekapan dan membuat laporan hasil monitoring kegiatan pembelajaran. Tidak hanya itu, hampir semua kegiatan monitoring dan evaluasi dilakukan secara manual sehingga membutuhkan waktu yang cukup lama untuk mendapatkan hasilnya. Oleh karena itu maka dibutuhkan dukungan sistem informasi yang dapat mengakomodasi kebutuhan dari sistem penjaminan mutu termasuk monitoring kegiatan pembelajaran, kegiatan penelitian dosen dan pengabdian kepada masyarakat. Dengan adanya sistem informasi monitoring, LPMI UNVIC Sorong dengan mudah melakukan evaluasi kegiatan Tri dharma terhadap standar yang ditetapkan oleh LPMI berdasarkan SN-Dikti serta dapat memberikan laporan yang dapat dilihat langsung oleh pimpinan melalui dashboard dengan akun pimpinan. LPMI UNVIC Sorong saat ini telah memiliki sistem informasi monitoring berbasis aplikasi web, yang memiliki beberapa pengguna sistem anatara lain mahasiswa, dosen, pimpinan PT, dan pengelola sistem adalah LPMI UNVIC Sorong. 
Kegiatan pengabdian yang dilakukan untuk implementasi sistem monitoring kegiatan Tri dharma PT oleh LPMI UNVIC Sorong yang ditujukan kepada mahasiswa, dosen, dan pimpinan di Universitas Victory Sorong, berupa workshop pemanfaatan sistem informasi monitoring dengan fungsi dan prosedur sistem untuk semua akun yang terdaftar dalam sistem.

\section{MASALAH}

Berdasakan uraian pendahulan dirumuskan beberapa masalah yang dialami oleh LPMI UNVIC Sorong anatara lain:

a. Proses monitoring kegiatan Tri dharma masih dilakukan secara manual yaitu dengan menggunakan formulir dan dokumen yang berbentuk kertas.

b. Belum adanya pemanfaatan sistem informasi yang dapat mendukung sistem monitoring dan evaluasi kegiatan Tri dharma PT secara online.

Implementasi pemanfaatan sistem informasi monitoring untuk kegiatan Tri dharma dilakukan pada LPMI UNVIC Sorong berupa kegiatan workshop penggunaan sistem pada semua pengguna yang terlibat dalam sistem. Hasil kegiatan mengharapkan tercapainya peningkatan kinerja LPMI UNVIC Sorong dalam melakukan monitoring dan evaluasi kegiatan pembelajaran, penelitian dosen dan pengabdian kepada masyarakat, serta memberikan laporan secara online kepada pimpinan PT melalui dashboard pimpinan.

\section{METODE}

\subsection{Metode Penyelesaian dan Pelaksanaan Kegiatan}

Pemaanfaatan sistem informasi dan teknologi informasi menjadi suatu solusi dalam meningkatkan kinerja sistem penjaminan mutu internal pada PT, terutama dalam menjalankan fungsi pelaksanaan monitoring kinerja akademik PT meliputi kegiatan pendidikan dan pengajaran, penelitian, serta kegiatan pengabdian kepada masyarakat. Implementasi sistem informasi melibatkan pengguna yang menjadi indikator penentu dalam penilaian mutu pendidikan pada PT, pengguna harus memahami penggunaan sistem, karena pengguna memiliki peran dan fungsi untuk menjalankan prosedur dalam sistem. Untuk itu tahapan dalam implementasi sistem membutuhkan kegiatan pelatihan terhadap pengguna.

LPMI UNVIC Sorong telah memiliki dan mengimplementasi sistem informasi monitoring kegiatan Trihdarma PT berbasis online. Tahapan implementasi sistem penjaminan 
mutu adalah dengan melakukan kegiatan workshop pemanfaatan sistem informasi monitoring kegiatan tri dharma PT kepada mahasiswa, dosen dan pimpinan PT. Kegiatan workshop dilaksanakan pada tanggal 07 - 08 September 2018 bertempat di Universitas Victory Sorong.

\subsection{Sistem Penjaminan Mutu Internal (SPMI)}

SPMI adalah kegiatan sistemik penjaminan mutu Pendidikan tinggi oleh setiap perguruan tinggi secara otonom atau mandiri untuk mengendalikan dan meningkatkan penyelenggaraan Pendidikan tinggi secara berencana dan berkelanjutan. SPMI di suatu perguruan tinggi merupakan kegiatan pengembangan mendiri dari perguruan tinggi yang bersangkutan sehingga proses tersebut dirancang, dijalankan, dan dikendalikan sendiri oleh perguruan tinggi yang bersangkutan tanpa campur tangan pihak lain (Fachruddin, 2014). Sekalipun setiap perguruan tinggi dapat mengembangkan SPMI secara otonom atau mandiri, namun terdapat hal mendasar yang harus ada di dalam SPMI setiap perguruan tinggi.

Di dalam Pasal 52 ayat (2) UU Dikti disebutkan bahwa penjaminan mutu dilakukan melalui 5 (lima) langkah utama yang disingkat PPEPP, yaitu Penetapan, Pelaksanaan, Evaluasi (pelaksanaan), Pengendalian (pelaksanaan), dan Peningkatan Standar Dikti. Hal ini berarti bahwa kelima langkah utama tersebut harus ada dalam melaksanakan SPMI, bahkan merupakan inti dari SPMI di setiap perguruan tinggi. Lima langkah utama, yaitu PPEPP, di dalam SPMI suatu perguruan tinggi merupakan proses implementasi Standar Dikti dalam SPMI.

Menurut Pasal 54 UU Dikti, standar yang harus digunakan di dalam SPMI setiap perguruan tinggi adalah Standar Dikti yang terdiri atas SN Dikti yang ditetapkan oleh Menteri, dan Standar Dikti yang ditetapkan oleh setiap perguruan tinggi dengan mengacu pada SN Dikti. SN Dikti merupakan satuan standar yang meliputi Standar Nasional Pendidikan ditambah dengan Standar Nasional Penelitian, dan Standar Nasional Pengabdian Kepada Masyarakat. Sementara itu, Standar Dikti yang ditetapkan oleh setiap perguruan tinggi terdiri atas sejumlah standar dalam bidang akademik dan bidang nonakademik yang melampaui SN Dikti. SN Dikti sebagai standar yang ditetapkan oleh Pemerintah, telah ditetapkan dalam Permenristekdikti No. 44 Tahun 2015 Tentang SN Dikti. 


\subsection{Sistem Monitoring}

Monitoring merupakan tindakan mengevaluasi pelaksanaan standar lazim dikaitkan dengan tindakan memantau (monitoring), sehingga dapat disingkat menjadi 'monev'. Evaluasi adalah penilaian terhadap suatu proses atau kegiatan yang telah selesai dilakukan, yang disebut juga sebagai summative evaluation. Evaluasi seperti ini bersifat komprehensif dan utuh, sehingga bukan hanya hasil (output) yang dinilai melainkan juga dampak atau (outcomes) dari sebuah proses atau kegiatan. Monitoring adalah penilaian pula, tetapi dilakukan ketika kegiatan yang dinilai itu masih berjalan, atau disebut sebagai formative evaluation. Monitoring juga didefenisikan sebagai proses rutin pengumpulan data dan pengukuran kemajuan atas objektif program, memantau perubahan yang fokus pada proses dan keluaran. Monitoring melibatkan perhitungan atas apa yang kita lakukan, monitoring melibatkan pengamatan atas kualitas dari layanan yang kita berikan.

Sistem monitoring merupakan salah satu elemen kerja yang dilakukan oleh tim pengendalian penjaminan mutu. Tujuan kegitan monitoring adalah (a) memastikan Standar dalam SPMI (Standar Dikti) telah dilaksanakan sebagaimana telah ditetapkan; (b) mengantisipasi dan/atau mengoreksi kekeliruan atau kekurangan yang terjadi dalam pelaksanaan Standar yang berpotensi menggagalkan pencapaian isi Standar dalam SPMI (Standar Dikti) tersebut; dan (c) jika tidak ditemukan kekeliruan atau kekurangan, maka tujuan evaluasi atau monitoring adalah mempertahankan pelaksanaan Standar dalam SPMI (Standar Dikti) yang telah berlangsung.

\subsection{Kegiatan Tri Dharma Perguruan Tinggi}

Tri dharma Perguruan Tinggi yang terdiri dari Pendidikan dan Pengajaran, Penelitian dan Pengembangan, serta Pengabdian kepada Masyarakat adalah tugas pokok PT di Indonesia dalam menyelenggarakan pendidikan Nasional (Sani et al., 2015). Misi suatu perguruan tinggi tercermin dalam kegiatan Tri Dharma Perguruan Tinggi-nya, sesuai dengan falsafah yang diamanatkan oleh pemerintah bagi institusi.

Tri dharma PT merupakan tugas pokok yang harus dijalankan oleh dosen pada PT yang terdiri dari: (1) Pendidikan dan Pengajaran di Perguruan Tinggi adalah kegiatan mempersiapkan, menyampaikan dan mengevaluasi informasi ilmiah. (2) Penelitian adalah kegiatan penyelidikan menurut metode ilmiah yang sistematik untuk menemukan informasi ilmiah dan teknologi yang baru, membuktikan kebenaran atau ketidak benaran hipotesa 
sehingga dapat dirumuskan teori atau proses gejala alam dan atau sosial. (3) Pengabdian kepada masyarakat adalah pengamalan pengetahuan, teknologi, dan seni yang dilakukan oleh tenaga pengajar secara melembaga, yang hasilnya bermanfaat bagi usaha mencerdaskan bangsa (Suheri, 2017).

\section{HASIL DAN PEMBAHASAN}

Implementasi sistem monitoring kegiatan Tri dharma pada UNVIC Sorong dilakukan dengan melaksanakan workshop pemanfaatan sistem untuk penguna sistem antara lain mahasiswa, dosen, dan pimpinan PT. Kegiatan ini dilakukan selama dua hari, hari pertama untuk dosen dan pimpinan PT serta hari kedua untuk mahasiswa. Peserta yang hadir dalam kegiatan workshop untuk dosen dan pimpinan yang terdaftar dalam sistem sebanyak 46 orang sedangkan untuk mahasiswa sebanyak 63 orang.
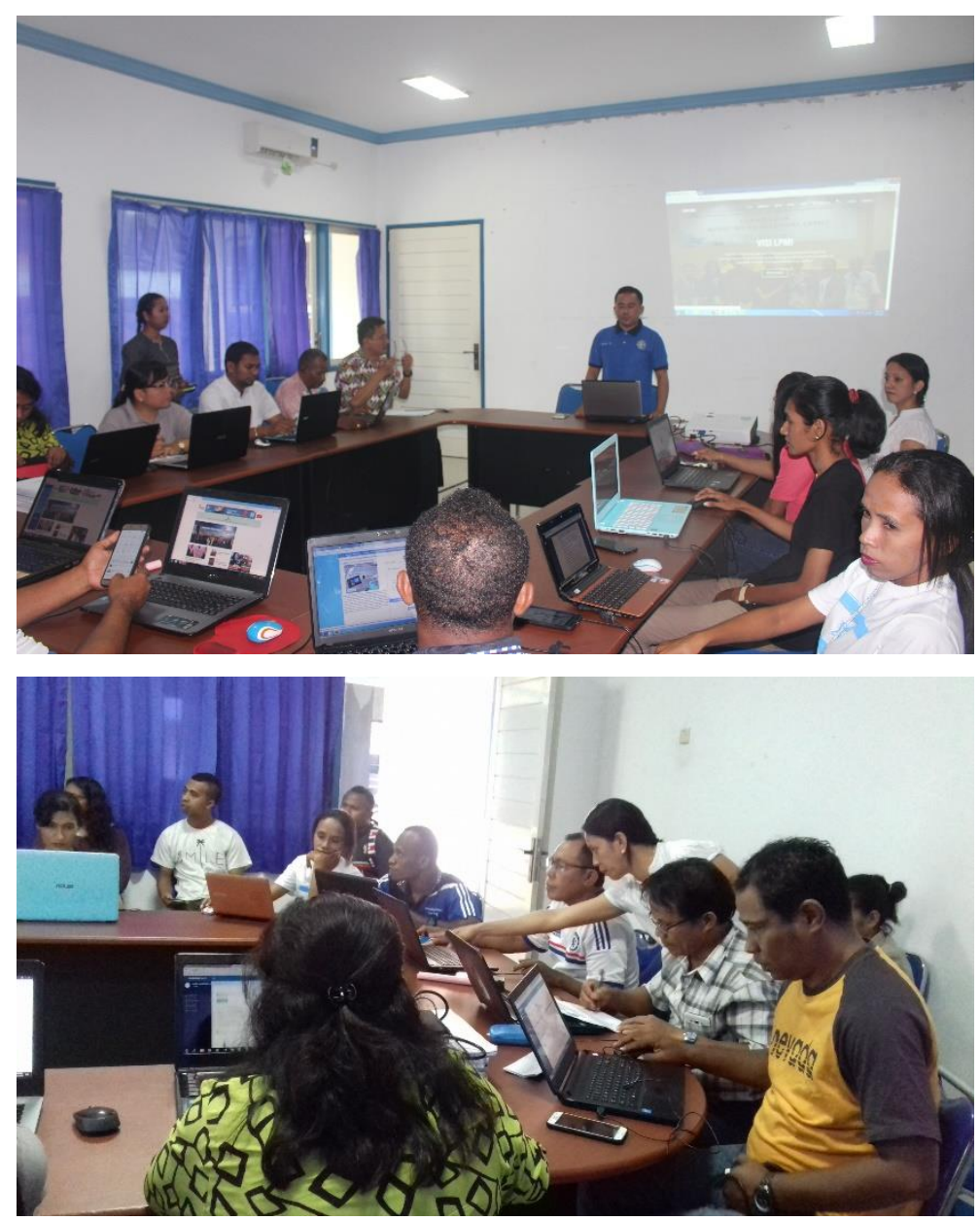


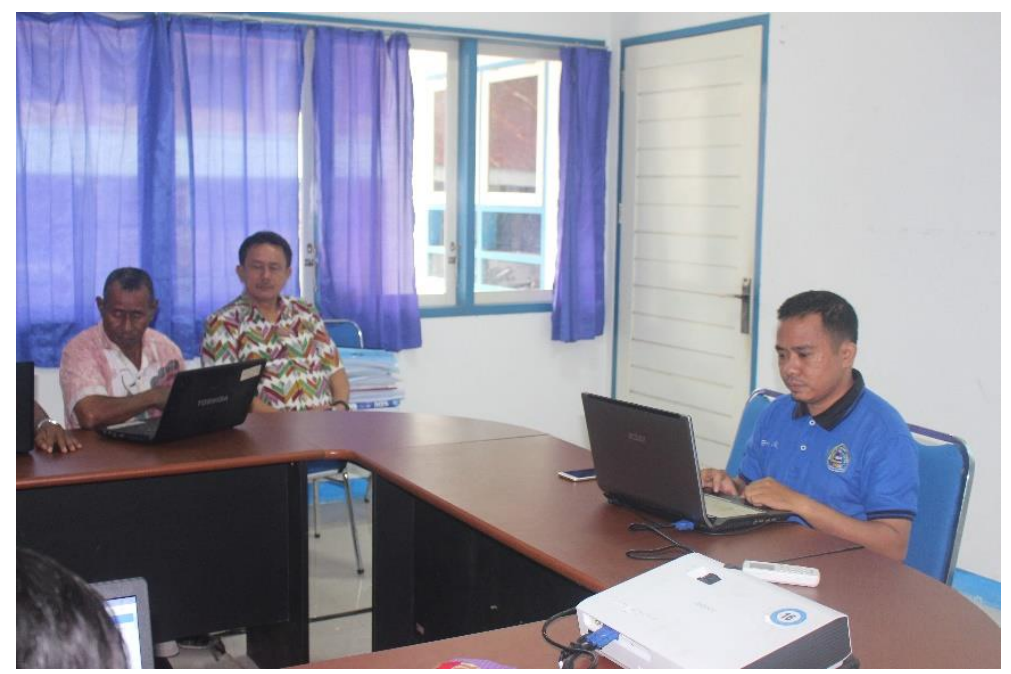

Gambar 1. Kegiatan Workshop untuk Dosen dan Pimpinan PT

Kegiatan workshop untuk dosen dan pimpinan PT pada hari pertama dilaksanakan dengan metode pelatihan penggunaan sistem yang menjadi tugas dan peran pengguna dalam sistem. Peran dosen dalam sistem adalah setiap kegiatan Tri dharma dosen harus dilaporkan dalam sistem melalui dashboard dosen, baik kegiatan pembelajaran, penelitian, dan kegiatan pengabdian kepada masyarakat, setiap dosen diberikan akun untuk melakukan login pada sistem untuk melakukan pelaporan data, selain itu dosen juga bisa melihat aktivitas kegiatannya dalam sistem. Sedangkan peran pimpinan dalam sistem adalah melakukan monitoring kegiatan Tri dharma dalam PT pada semua program studi melalui dashboard pimpinan. Akun untuk login ke dashboard pimpinan diberikan kepada Rektor, Wakil Rektor I, dan juga Lembaga Penjaminan Mutu Internal selaku pengelola sistem. Peran pimpinan dalam sistem juga bisa melihat, memonitoring kegiatan pembelajaran dosen dan mahasiswa di kelas melalui laporan data mahasiswa yang ditugaskan untuk mengisi jurnal perkulihan dalam sistem, pimpinan bisa juga melihat laporan data kegiatan penelitian dan pengabdian kepada masyarakat untuk dosen. 


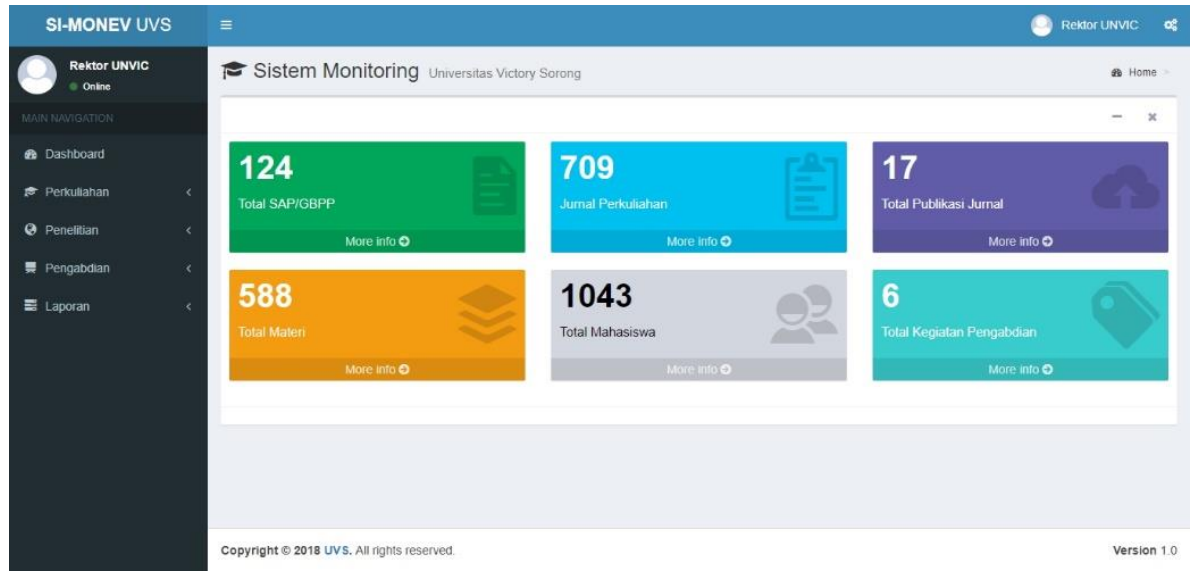

Gambar 2. Halaham dashboard pimpinan PT

Kegiatan workshop untuk mahasiswa pada hari kedua diawali dengan memberikan akun kepada mahasiswa untuk melakukan login ke sistem. Mahasiswa yang hadir pada kegiatan pelatihan adalah mahasiswa perwakilan dari setiap kelas/semester untuk semua program studi pada UNVIC Sorong.
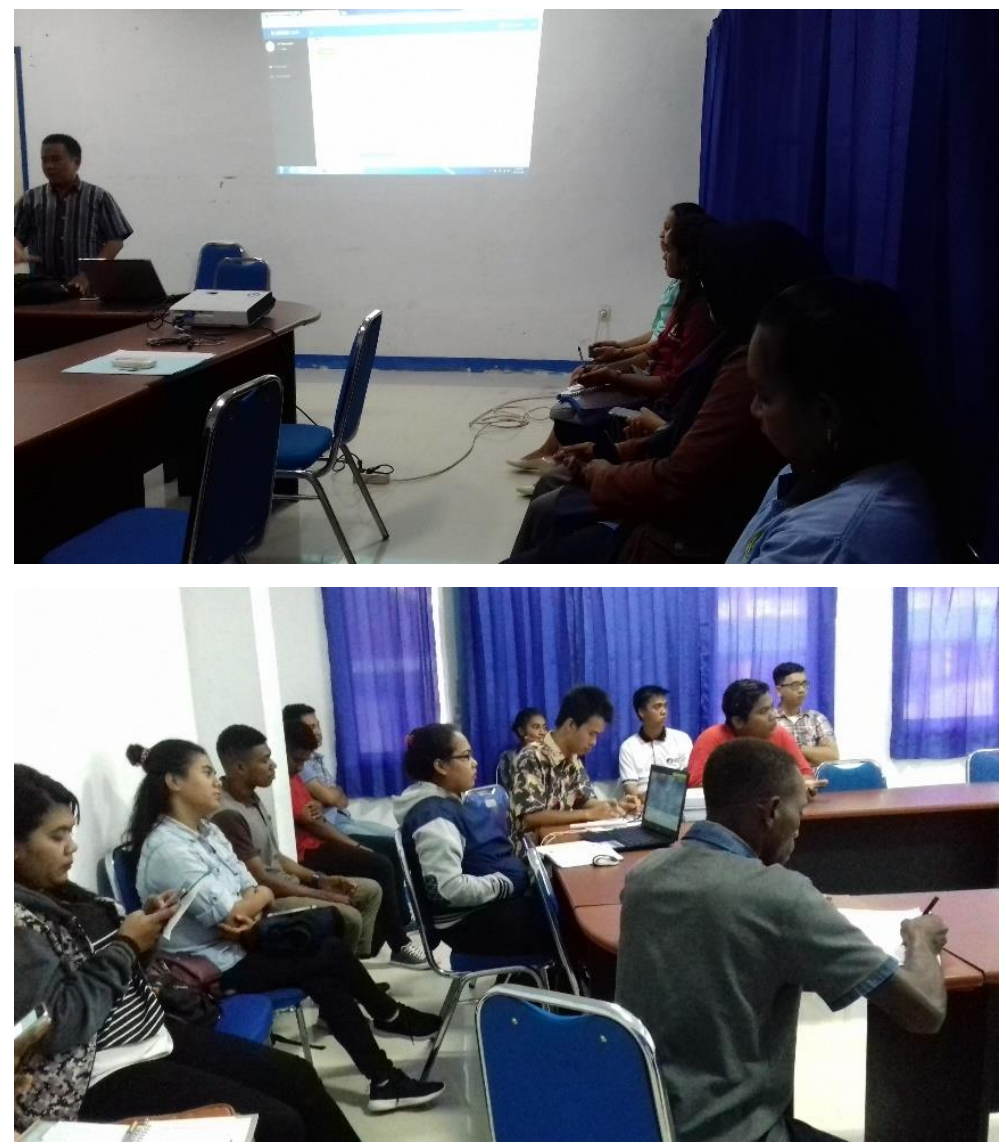


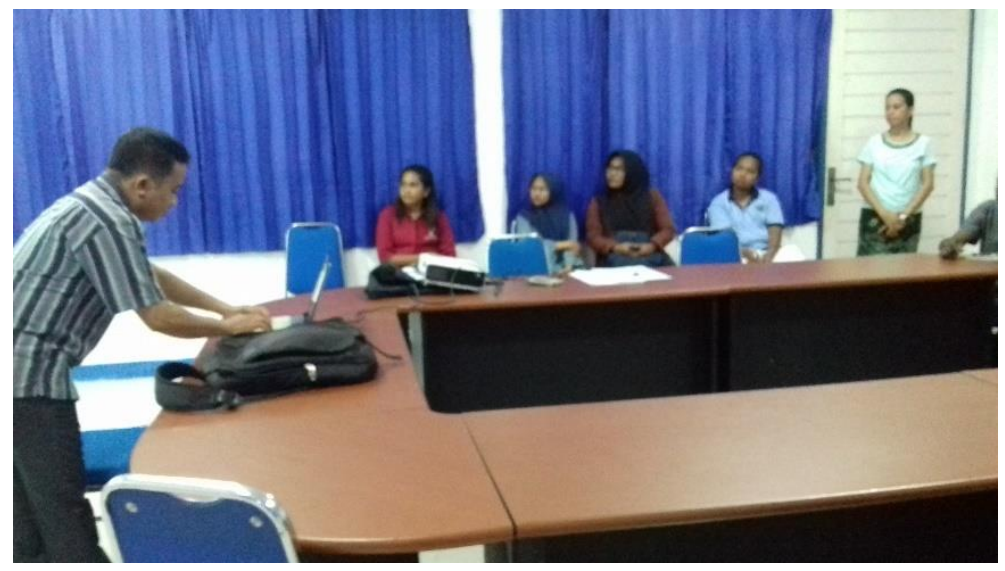

Gambar 3. Kegiatan Workshop untuk Mahasiswa

Peran mahasiswa dalam sistem adalah melakukan pengisian jurnal setiap kali proses perkuliahan dilaksanakan di kelas melalui dashboard mahasiswa. Laporan data jurnal perkuliahan yang diinput oleh mahasiswa dalam sistem bisa langsung dilihat oleh mahasiswa dan pimpinan PT.

\section{KESIMPULAN}

Sistem monitoring merupakan tindakan mengevaluasi pelaksanaan standar yang menjadi salah satu elemen kerja yang dilakukan oleh tim pengendalian penjaminan mutu internal pada PT. Tujuan kegitan monitoring adalah memastikan standar dalam SPMI (Standar Dikti) telah dilaksanakan sebagaimana telah ditetapkan dan mengoreksi kekeliruan atau kekurangan yang terjadi dalam pelaksanaan standar yang berpotensi menggagalkan pencapaian isi standar serta jika tidak ditemukan kekeliruan atau kekurangan, maka tujuan evaluasi atau monitoring adalah mempertahankan pelaksanaan standar dalam SPMI yang telah berlangsung. Permasalahan yang terjadi pada LPMI UNVIC Sorong adalah kesulitan dalam melakukan monitoring dan evaluasi kegiatan Tri dharma PT karena dilakukan secara manual sehingga membutuhkan waktu yang cukup lama untuk mendapatkan hasil evaluasi dan monitoring.

Pemanfaatan sistem informasi menjadi solusi yang mendukung semua kegiatan penjaminan mutu termasuk monitoring dan evaluasi terhadap pelaksanaan standar mutu. LPMI UNVIC Sorong saat ini telah memiliki sistem informasi berbasis aplikasi online yang mendukung kegiatan Tri dharma PT, implementasi sistem ini membutuhkan sosialisasi dan pelatihan kepada pengguna yang terdaftar dalam sistem. Kegiatan ini merupakan kegiatan 
pengabdian yang dilakukan berupa kegiatan workshop pemanfaatan sistem informasi

monitoring terhadap pengguna sistem antara lain mahasiswa, dosen, dan pimpinan PT, pelaksanaan kegiatan ini memastikan semua pengguna sistem telah mendapatkan akun untuk login ke sistem dan mengetahui peran, fungsi dan prosedur sistem dalam melaksanakan kegiatan Tri dharma PT. Sistem ini akan mengahsilkan output berupa laporan data kegiatan Tri dharma yang meliputi pembelajaran di kelas, penelitian dan kegiatan pengabdian masyarakat yang secara langsung dapat dilihat dan dimonitoring oleh pimpinan PT.

\section{DAFTAR PUSTAKA}

Fachruddin. (2014). Sistem Informasi Monitoring Dan Evaluasi Perkuliahan (Studi Kasus : STIKOM Dinamika Bangsa), 8(3), 45-57.

Peraturan Menteri Riset, Teknologi, dan Pendidikan Tinggi Republik Indonesia Nomor 44 Tahun 2015 Tentang Standar Nasional Pendidikan Tinggi.

Rupilele, F. G. J., Soulisa, I., Palilu, A., Hasibuan, A., Winesty, O. F., Goraph, F. A., ... Tondo, S. (2018). Management Information System for Monitoring and Inspection of the Implementation of Universities, 7, 451-456.

Sani, N. A., Roestam. W., Hendrianie. N., Mudjahidin. (2015). Perancangan Model Sistem Informasi Evaluasi Dan Monitoring Pelaksanaan Tri dharma Perguruan Tinggi. Seminar Nasional Sistem Informasi Indonesia.

Suheri, A. (2017). Sistem Monitoring Kineja Dosen Dalam Kegiatan Tri Dharma Perguruan Tinggi (Studi Kasus STMIK Cilegon). Media Jurnal Informatika, Vol. 9, No.1, 37-48.

Undang-undang Republik Indonesia Nomor 12 Tahun 2012 Tentang Pendidikan Tinggi.

https://umm.usu.ac.id/kegiatan-dan-program/monitoring-dan-evaluasi-smm/(diakses 29-102018) 